\title{
Sustainable Development and Transport
}

\author{
J. Jedlička*, I. Dostál, V. Adamec \\ Division of Transport Infrastructure and Environment, Transport Research Centre, Brno, Czech Republic \\ Corresponding author: jiri.jedlicka@cdv.cz
}

DOI: $10.2478 / \mathrm{v} 10158-011-0013-9$

\begin{abstract}
Transport is one of the crucial factors in the development of individual countries. However, there is a constant contradiction between society, which requires ever higher mobility, and the public opinion, which is less and less tolerant towards the negative impact transport has on the environment and health, chronic delays, and the low quality of some transport services. Considering the fact that transport demands are rising steadily, we should not be restricted only to the construction of new infrastructure and opening markets. It is necessary to optimize the transport system so that it meets the requirements for sustainable development. The modern transport system has to be sustainable, in terms of economy, social, and the environmental aspects.
\end{abstract}

KEY WORDS: transport, sustainable development, environment, means of transport.

\section{SUSTAINABLE DEVELOPMENT}

Development and its sustainability are issues which gain global dimensions and time urgency. Originally separated issues concerning the development - how to assure a good and safe life for all people on Earth; and sustainability - how to live within the environmental rules and limits, have combined together into one - how should we and our children live on this planet without exceeding the degree of its bearing capacity and limit the ability of future generations (Meadows et al., 1992). The basis of sustainable development is so extensive that there is no single definition which would be able to cover the complexity of the concept, which is reflected in a wide variety of definitions and interpretations. Individual interpretations and approaches to sustainable development differ according to the fact whether they lay emphasis on the environmental, social, or economic perspective. The economic approach emphasizes efficiency, growth, stability, intergenerational equity, and employment. The social approach focuses on poverty, cultural heritage, intergenerational equity, citizens' participation in decision-making processes, and employment. The environmental approach pays attention to biodiversity, natural resources, and environmental pollution.

The concept of sustainable development represents an alternative model of society's development which corresponds with the new situation of the contemporary world, which has radically changed recently. The reflection of the natural environmental limits on economic growth was missing in society before the occurrence of the concept of sustainable development. However, soon after the onset of the Industrial Revolution, the voices of economists and demographers (Mill, 2004, Malthus, Flew, 1983) on the impossibility of unlimited economic growth resounded, particularly when it was connected with population 
growth. A new term "global issues" emerged in the 1960s whose urgency was noted in connection with the globalization of human civilization, which created the basis for a consuming society. The term was introduced and then spread, especially in connection with the activity of Club of Rome, which was established in 1968 in Rome and brought together important scientists, cultural, and political personalities, as well as representatives of industry. Theories and methods of this club are based on the assumption that mankind is currently in a critical situation and it is essential to monitor global issues in a complex way, taking the mutual coherence of all parts of the environment into consideration. This development of opinions is contemporarily being developed, particularly in developed countries, towards the improvement of development in this context, and sustainable development represents a new strategy framework for civilization's development in this connection. This approach comes from a report of the UN Commission for the Environment and Development (Bruntland, 1987) that considers such development to be sustainable and which will assure the needs of current generations without compromising the needs of future generations and additionally without being at the expense of other nations. The definition of sustainable development in the Czech legislation is dealt with by the Environmental Act No. 17/1992, as amended, as follows: sustainable development is such development which provides current and future generations with the opportunity to satisfy their basic living needs and does not reduce natural diversity and preserves the functions of the natural ecosystem.

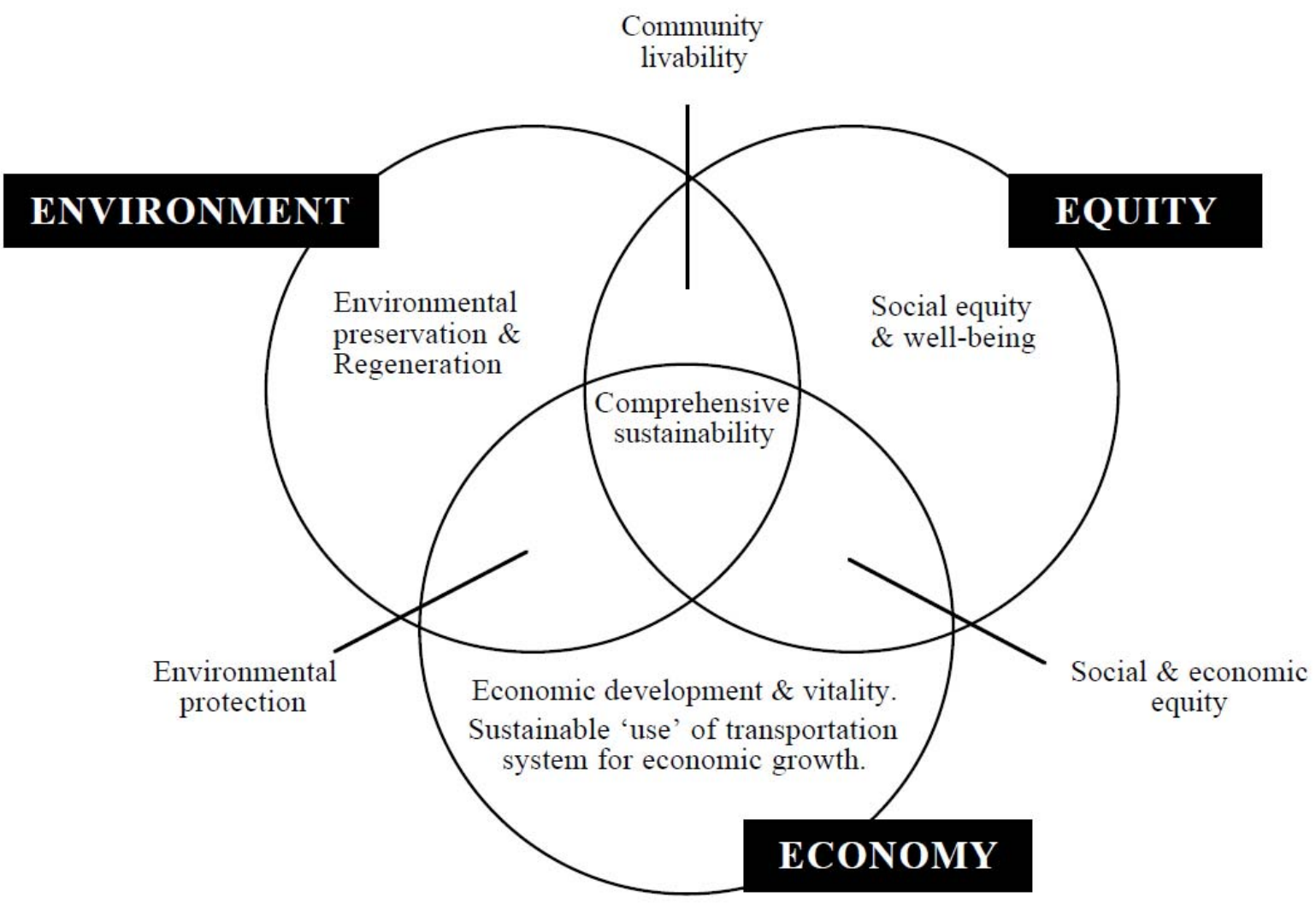

Figure 1: Definition of sustainable transport (Marks, 2002).

The World Summit on Sustainable Development, held in Johannesburg in 2002, pointed out again that it is necessary to promote such development which will assure the balance 
between all three basic pillars: social, economic, and the environmental. The conclusions adopted at this summit included the determination of the fundamental principles of sustainable development which are mentioned in Table 1.

Table 1: Basic principles of sustainable development.

\begin{tabular}{|l|l|}
\hline \multicolumn{1}{|c|}{ Principle } & \multicolumn{1}{c|}{ Description } \\
\hline $\begin{array}{l}\text { The connection } \\
\text { of fundamental areas of } \\
\text { life }\end{array}$ & $\begin{array}{l}\text { It concerns three fundamental pillars: economic, social } \\
\text { and the environmental. }\end{array}$ \\
\hline The long-term perspective & $\begin{array}{l}\text { Each decision has to be considered in terms of long-term } \\
\text { impacts; they have to be planned strategically. }\end{array}$ \\
\hline $\begin{array}{l}\text { The capacity } \\
\text { of the environment } \\
\text { is limited }\end{array}$ & $\begin{array}{l}\text { Considering not only raw material resources, materials, } \\
\text { and functions necessary for life, but also space for waste } \\
\text { and contamination of all kinds. }\end{array}$ \\
\hline Preliminary carefulness & $\begin{array}{l}\text { The consequences of some of our actions are not always } \\
\text { known because our knowledge patterns operating } \\
\text { within the environment are still at a very low level } \\
\text { and therefore we have to be careful. }\end{array}$ \\
\hline Prevention & $\begin{array}{l}\text { Much more effective than consequent removal of impacts; } \\
\text { is to invest the funds in the solution of problems before they } \\
\text { have occurred than in the subsequent solution for impacts. }\end{array}$ \\
\hline Life quality & $\begin{array}{l}\text { It does not only include material, but social, ethical, aesthetic, } \\
\text { mental, cultural aspects, and others; people have a natural right } \\
\text { for a quality life. }\end{array}$ \\
\hline Social equity & $\begin{array}{l}\text { The opportunities and responsibilities should be divided among } \\
\text { countries, regions and various social groups as well. }\end{array}$ \\
\hline $\begin{array}{l}\text { Considering } \\
\text { the relationship } \\
\text { "local - global" }\end{array}$ & $\begin{array}{l}\text { The activities at the local level influence problems on a global } \\
\text { level - they create them or help them to be solved; it works } \\
\text { vice versa as well. }\end{array}$ \\
\hline $\begin{array}{l}\text { Intra-generational } \\
\text { and intergenerational } \\
\text { responsibility }\end{array}$ & $\begin{array}{l}\text { The assurance of national, racial, and other inequalities, } \\
\text { respecting the rights of all current and future generations } \\
\text { for a healthy environment and with social justice. }\end{array}$ \\
\hline Democratic processes & The involvement of the public from the initial planning phase. \\
\hline
\end{tabular}

It was further stated that the basic assumption for the achievement of sustainable development is the so-called "good governance", which means transparency, responsibility, integrity, appropriate management, effective and available services, partnership commitment, and permanent development of public administration institutions. The consideration of all aspects of society development, among which there are economics, society, the environment, and culture, leads to particular decisions which will support sustainable development. Development does not always have to mean only the increase of the material level. However, sustainable development also does not mean the limitation of material needs under a tolerable rate, but it rather deals with value orientation and the lifestyle connected with it.

A significant part of the economic pillar is transport, which, by its activity, concurrently influences the remaining two pillars of sustainable development, both in a positive and negative way. Not only due to this reason, but also in terms of sustainable planning and development, more attention is currently paid to transport. 


\section{SUSTAINABLE DEVELOPMENT IN THE INTERNATIONAL CONTEXT}

The current and planned development in the transport sector aims to reach gradual reduction of negative impacts on the environment and human health by transport infrastructure and traffic operation. The fundamental assumption for this fact is to meet sustainable development principles resulting from international conferences dealing with this issue, national strategic plans of individual resorts, and the Sustainable Development Strategy of the Czech Republic. Among the main international events which currently influence the content and activity focus regarding transport, environment, and health, there is the UN Conference on the Environment and Development, the so-called "Earth Summit", 19th UN General Assembly session, the so-called "Rio+ 5", also known as "Earth Summit II" (1997), the UN Conference on Sustainable Development (2002), the so-called "Earth Summit III", and the annual meetings of the Commission for Sustainable Development (CSD).

The Organization for Economic Cooperation and Development (OECD) is paying more attention to the issues of sustainable development as well. Fundamental documents which should provide an idea to this organization's policy were approved at the regular meeting of the OECD Ministerial Council in May 2001. Sustainable development is marked in the final communique as the overarching goal of the governments of OECD countries.

The meeting approved the fundamental political document "Measures to strengthen sustainable development", in which it stated that sustainable development requires a broad concept of human welfare, and focuses on those areas where the most serious risks of unsustainability appear. Among these important areas is primarily the separation of the environmental burden from economic growth. The following goals are identified as crucial (Janic, 2006):

- development of approved indicators which measure the progress in all three dimensions of sustainable development, including the separation of economic growth and the impact on the environment,

- identification of ways in which to overcome obstacles to reform the developing policy, especially the better use of market-oriented tools and a reduction of environmentally harmful subsidies,

- continuation of the social aspect analysis of sustainable development,

- production of guidance for integration and the coherence of economic, social, and environmental areas.

Additionally, the European Union (EU), in the so-called Amsterdam Treaty on the European Union, effective since 1 May 1999, assigns "the balanced and sustainable development" significance comparable to the aim of "economic and social progress". Environmental protection is included in the main goals of the Community in article 2: "high level of air quality protection and improvement". The requirement of environmental aspect integration in other areas, mainly in the economic policy sector, is embedded in article 6. Two important documents have been passed at the international conference in Göteborg (2001):

- Proposal of the 6th Environmental Protection Action Plan with five main objectives (defence against climate change, natural conservation, ensuring a good environment in terms of health protection, protection of natural resources, and waste management).

- "Sustainable Development Strategy of the European Union" with six areas which should be dealt with as priorities: climate change and clean energy, public health, management 
of natural resources, poverty and social exclusion, population ageing and demography, mobility, land-use, and urban development.

The EU follows the Lisbon Summit (2000) and joins four other objectives in the environmental and economic area to the two goals of the social field so it completes the overall strategy for the next period. Based on these facts and following the survey of the EU Sustainable Development Strategy, which was initiated by the Commission in 2004 and the Commission statement titled "The Evaluation of Sustainable Development Strategy Action Platform" in December 2005, the European council adopted the complex renewed strategy of sustainable development for the EU enlargement, and, in June 2006, published the results from the strategy adopted in 2001. The main goals of the renewed strategy are as follows:

- Environmental protection - To assure that the Earth is able to maintain life in all its varieties, to maintain the limited quantity of natural resources of the planet and to assure the high level of protection of and improvement of the quality of the environment. To avoid environmental pollution and support its reduction, and support sustainable consumption and production, so that economic growth is not connected with environmental deterioration.

- Social equity and coherence - To support democratic, coherent, healthy, safe, and fair society, which supports social integration, maintains fundamental rights and cultural variety, which creates equal opportunities, and which fights against all forms of discrimination.

- Economic prosperity - To support the prosperous, innovative, competitive and environmental economy based on a wealth of knowledge which brings high standards of living, and full and quality employment throughout the whole European Union.

- Meeting the international commitments - To support the worldwide establishment of democratic institutions based on peace, safety, and freedom, and to defend their stability. Actively support sustainable development throughout the whole world and assure that internal and external policies of the European Union be consistent with global sustainable development and its international commitments.

The major objectives mentioned in the renewed Strategy are elaborated in the "transport" section in the following measures:

- To take measures to improve the economic and environmental performance of all transport modes and take appropriate measures for transferring road transport onto rail and water transport, and the use of public transport; the measures also include a reduction in traffic intensity through the re-organizing of production and logistic processes and a change of behaviour together with the better interconnection of various transport modes.

- To increase energy efficiency in the transport sector using cost-effective instruments. To focus on possible alternatives of freight and passenger road transport, including the development of the Trans-European Transport Network and combine connections for freight transport, e.g. by implementing the measures determined in the Commission action programme for Inland Waterway Transport, titled "NAIADES" and "Marco Polo II" programme. 
- To examine the use of infrastructure charging for all types of transport based on new opportunities which are emerging in connection with new satellite information and communication technologies, within the scope of directive 1999/62/EC on charging fees for using certain roads by heavy vehicles. Not later than in 2008, the Commission will submit a generally usable, transparent, and complex model of assessment of all external costs which should be used as a basis for future calculations of the infrastructure charging.

- To strive for effective worldwide solutions, as far as the reduction of negative impact of international naval and air transportation is concerned.

- To reduce the number of deaths in the road transport by half and reduce the number of injured, increase road traffic safety by improving the road infrastructure, increase vehicle safety by promoting joint European-wide awareness campaigns in order to change the behaviour of road users, and through the introduction of crossborder enforcement rights.

- The city authorities should produce and execute the plans and systems of city transport while taking into account the guidelines which were issued by the Commission in 2006 and with consideration of all closer cooperation of cities within adjacent areas, in accordance with the strategy for urban environment.

- To produce a long-term and consistent strategy concerning fuels.

The above-mentioned goals, which were determined by the renewed strategy of sustainable development of the EU, are also being transformed to Strategy for Sustainable Development of the Czech Republic and subsequent strategic and conceptual materials of the individual ministries, such as the Transport Policy for 2005-2013.

\section{SUSTAINABLE DEVELOPMENT IN THE CZECH REPUBLIC}

Sustainable development started to be applied in the Czech Republic as a modern principle of development after 1989. In the late 1990s three environmental policies in total were produced and adopted, which emphasized the notion of sustainable development. The first strategic material was the so-called "Rainbow programme" of the Ministry of the Environment in 1990, which considered the principle of sustainable development to be one of the fundamental ones. The preparation and approval of the first generation of the environmental legislation (including Acts on waste, air pollution, nature and landscape conservation, and environmental impact assessment) were its main features. The new legal regulations focused on reaching the highest possible increase in environmental status within the shortest possible time and comprised of the whole range of "transformation elements" (e.g. a very strict regime of cross-border movement of waste). The existing or newly established institutions of public administration (especially the Ministry of the Environment and the Czech Environmental Inspection) and supporting institutions (e.g. the State Environmental Fund, the Czech Environmental Institution) were transformed or newly established together with legislation. The "revolutionary" Rainbow programme was replaced with the "State Environmental Policy" in 1995, which was an apparent step backwards. It omitted a range of modern demands on environmental protection (e.g. the integration of environmental demands in the other sector policies) and it was exceedingly determined by blind technocratic economism of that time. This policy utterly omitted the principle of sustainable development explicitly; however, it stood for the basic 
requirements of intra-generation responsibility (Třebícký et al., 2001). The new State Environmental Policy, compatible with environmental policy of European Communities, which considers sustainable development to be its basic starting point, was adopted in 2000 (and amended in 2001). The Government of the Czech Republic approved or took into account some sector policies in the course of $1997-2000$, which stood for the sustainable development principles to a greater or lesser extent. In its Programme statement the government even states that sustainable development is considered to be one of its fundamental objectives. However, it was apparent that by 2002 no fundamental document had managed to address the issue of sustainable development across the required range. In 2002, a team of authors from Charles University Environment Centre in Prague produced a proposal for a national strategy for the sustainable development of the Czech Republic. This document had the goal to fill in the existing absence of concise and sufficiently complex material, which would contribute to a desirable transformation of the social and economic development of the Czech Republic in the interests of its sustainability.

In spite of this very progressive document, it took another two years, until 8 December 2004, when the Strategy for Sustainable Development of the Czech Republic (SUR) was approved by government resolution number 1242. The fundamental goal of this strategic document was to point out the existing and potential problems which could threaten the transition of the Czech Republic towards sustainable development, and initiate the measures to avoid or at least mitigate these threats. SUR ČR has become a fundamental document for the processing of other conceptual materials, such as sector policies, as well as action plans. The strategy defines the main objectives, further sub-goals, and instruments. The main objectives are based on three pillars - economic, environmental, and social and they are accompanied by four other areas - research and development, education, European and international context and, last but not least, the governance of public issues. The proposed objectives lead to a guarantee of the highest possible life quality for current generations and to ensure the quality life of future generations. The basic time framework of SUR is 2014, however, some considerations and objectives will take until 2030.

The document "Renewed Strategy for the Sustainable Development of the Czech Republic", which results from principles mentioned in the original Strategy, and specifies some of their starting points, was published in May 2007. The renewed strategy is divided into twelve areas, which are based on the six original ones mentioned in the text; however, they make them more explicit and complete, especially considering the renewed SUR of the European Union. The determination of objectives within twelve fields is made with regard to the basic idea of sustainable development, which looks for harmony between the three basic pillars. This strategy is further completed with three cross-sections, which are life quality and freedom of choice, development and the maintenance of the Czech landscape, and the separation of development curves of economic performance from the impact on the environment. SUR completes these fields with approaches which exceed and integrate the individual areas and pillars at the same time.

Work on updating SUR CR led to the production of the document "Strategic Framework for the Sustainable Development of the Czech Republic" (SRUR) which was approved on 11 January 2010 by the Government Resolution No. 37.

This document is of an all-resort cross-sectional nature. SRUR informs the government authorities and summarizes the general level of key topics, problems, and possible solutions. Its objective is not to save specific measures or replace the resort or cross-sectional strategies, but to support their long-term orientation and mutual interconnection. The time horizon of SRUR is 2030. An important task is to prepare a text about sustainable development within the implementation of the SUR text on sustainable development which will contain 
the binding tasks, verifiable targets, and, especially, the binding decisions and verifiable cost estimates and impacts. SRUR priorities and objectives are classified into five priority axes; the structure is shown in Table 2 .

Table 2: SRUR priorities and objectives.

\begin{tabular}{|c|c|c|c|c|}
\hline $\begin{array}{l}\text { Priority axis 1: } \\
\text { Society, people } \\
\text { and health }\end{array}$ & $\begin{array}{l}\text { Priority axis 2: } \\
\text { Economy } \\
\text { and innovation }\end{array}$ & $\begin{array}{c}\text { Priority axis 3: } \\
\text { Land use } \\
\text { development }\end{array}$ & $\begin{array}{l}\text { Priority axis 4: } \\
\text { Landscape, } \\
\text { ecosystems } \\
\text { and biodiversity }\end{array}$ & $\begin{array}{c}\text { Priority axis 5: } \\
\text { A stable } \\
\text { and secure } \\
\text { society }\end{array}$ \\
\hline $\begin{array}{l}\text { Priority 1.1: } \\
\text { Improving } \\
\text { the conditions } \\
\text { for healthy } \\
\text { lifestyle }\end{array}$ & $\begin{array}{c}\text { Priority 2.1: } \\
\text { Supporting } \\
\text { the dynamics } \\
\text { of the national } \\
\text { economy } \\
\text { and improving } \\
\text { competitiveness } \\
\text { (in industry } \\
\text { and business, } \\
\text { agriculture, } \\
\text { services) }\end{array}$ & $\begin{array}{l}\text { Priority } 3.1 \text { : } \\
\text { Fostering } \\
\text { territorial } \\
\text { cohesion }\end{array}$ & $\begin{array}{l}\text { Priority 4.1: } \\
\text { Landscape } \\
\text { conservation } \\
\text { as a prerequisite } \\
\text { for biodiversity } \\
\text { conservation }\end{array}$ & $\begin{array}{c}\text { Priority 5.1: } \\
\text { Fostering social } \\
\text { stability } \\
\text { and cohesion }\end{array}$ \\
\hline $\begin{array}{l}\text { Priority } 1.2 \text { : } \\
\text { Improving the } \\
\text { lifestyle and the } \\
\text { health status of } \\
\text { the population }\end{array}$ & $\begin{array}{c}\text { Priority } 2.2: \\
\text { Ensuring national } \\
\text { energy security } \\
\text { and improving } \\
\text { the energy } \\
\text { and raw material } \\
\text { intensity } \\
\text { of the economy }\end{array}$ & $\begin{array}{l}\text { Priority } 3.2 \text { : } \\
\text { Improving } \\
\text { the quality of life } \\
\text { of the population }\end{array}$ & $\begin{array}{l}\text { Priority 4.2: } \\
\text { Responsible } \\
\text { farming } \\
\text { and forestry }\end{array}$ & $\begin{array}{l}\text { Priority 5.2: } \\
\text { Efficient country, } \\
\text { good governance } \\
\text { and civil sector } \\
\text { development }\end{array}$ \\
\hline $\begin{array}{c}\text { Priority 1.3: } \\
\text { Adjusting } \\
\text { policies } \\
\text { and services to } \\
\text { demographic } \\
\text { development } \\
\text { and fostering } \\
\text { inter- } \\
\text { generational } \\
\text { and family } \\
\text { cohesion }\end{array}$ & $\begin{array}{l}\text { Priority 2.3: } \\
\text { Promoting human } \\
\text { resources } \\
\text { development, } \\
\text { supporting } \\
\text { education, } \\
\text { research and } \\
\text { development }\end{array}$ & $\begin{array}{c}\text { Priority 3.3: } \\
\text { Promoting } \\
\text { strategic } \\
\text { and land-use } \\
\text { planning more } \\
\text { efficiently }\end{array}$ & $\begin{array}{c}\text { Priority 4.3: } \\
\text { Adaptation } \\
\text { to climate change }\end{array}$ & $\begin{array}{c}\text { Priority 5.3: } \\
\text { Improving } \\
\text { the preparedness } \\
\text { to cope with } \\
\text { the impacts } \\
\text { of global } \\
\text { and other security } \\
\text { threats and risks } \\
\text { and strengthening } \\
\text { international links }\end{array}$ \\
\hline
\end{tabular}

Each of the priorities is further elaborated into individual goals which deal with the assumptions of meeting the priorities in greater detail. The objective of the Strategic Framework for the Sustainable Development of the Czech Republic is to create the consensual framework for the production of further materials of a conceptual nature, such as sector strategies, policies or action plans, and are thus an important basis for strategic decision-making processes within the individual resorts, regions, cities and communities, for inter-resort cooperation, as well as for the cooperation of non-interest groups. 
The assurance for the effective implementation of SRUR ČR is implemented in three fundamental steps:

1. Production of methodological recommendations for the strategic document preparation at the national level resulting from the principles of strategic planning and containing certain aspects (i) of priority and goal integration of the SRUR ČR in the appropriate resort strategic documents (newly being established or updated), evaluation of resort programmes compliance and plans with priorities and the goals of the SRUR ČR,

2. Providing additional necessary methodology consultations, instructions, and other help for ministries, regions, local authorities, and other partners of the SRUR ČR,

3. Introduction of a complex monitoring system for the implementation of the SRUR ČR by using of the existing information systems, indicators, and available data resources.

\section{INDICATORS OF SUSTAINABLE DEVELOPMENT}

It is necessary to determine the indicators which are used as an information system that shows the degree of development sustainability or unsustainability for a perception of the wide term of sustainable development, so that it can be used as a specific argument in desussions about development characteristics. The sustainable development strategy is a process of continuously seeking consensus between various interests whose success needs to be continuously evaluated, and to implement the information received in the decisionmaking process retroactively (Moldan, 2001), which means finding and defining indicators with a reasonable degree of explanatory power about the fact whether an agreed goal succeeds or fails. The indicators should meet some requirements among which are included: representativeness, real identifiability, simplicity and comprehension, price availability, and efficiency, in order to be really practically applicable. The last two requirements lead to the formulation of an indicator set which respects the well-known principle during the decision-making process "to make do with the minimum of available evidence".

One of the basic attributes of the indicators is an addressee or information receiver which is brought by the indicator itself. This pragmatic aspect states that to construct and measure any indicator is only worth doing when we can identify the individual or institution which is able or willing to use the acquired information in its decision-making process. (Moldan, 2001) All activities connected with the SUR ČR creation and updating production of situation reports with the evaluated indicator set and methodical coordination of conceptual documentation are provided by the Government Council for Sustainable Development and its working groups.

The Council is formed by central authority representatives of state administration, municipal authorities, social partners, academia, and the non-profit sector. The state of individual areas of sustainable development in the Czech Republic and the evaluation of meeting the SUR targets is being monitored by a set of indicators constructed on the basis of official data and verified methods, and the results are regularly published in the situation reports of the Strategy for the Sustainable Development of the Czech Republic, which is approved by the government. The existing indicators (ČSÚ, EUROSTAT, OECD, UN Commission for Sustainable Development) are within SRUR used to a maximum extent, so that their development over time (time series) can be followed. The indicators are designed for the individual priority axes and their overview is mentioned below. 
Table 3: SRUR indicators.

\begin{tabular}{|c|c|c|c|c|}
\hline Ecologi & & & & \\
\hline $\begin{array}{l}\text { Priority axis 1: } \\
\text { Society, people } \\
\text { and health }\end{array}$ & $\begin{array}{l}\text { Priority axis 2: } \\
\text { Economy } \\
\text { and innovation }\end{array}$ & $\begin{array}{l}\text { Priority axis 3: } \\
\text { Land use } \\
\text { development }\end{array}$ & $\begin{array}{l}\text { Priority axis 4: } \\
\text { Landscape, } \\
\text { ecosystems } \\
\text { and biodiversity }\end{array}$ & $\begin{array}{l}\text { Priority axis 5: } \\
\text { A stable } \\
\text { and secure society }\end{array}$ \\
\hline $\begin{array}{l}\text { I.A Standardized } \\
\text { mortality rate } \\
\text { by disease groups } \\
\text { I.B Population } \\
\text { exposure } \\
\text { to suspended } \\
\text { particulate matter } \\
\text { I.C Life } \\
\text { expectancy and } \\
\text { healthy life } \\
\text { expectancy } \\
\text { I.D Emissions, } \\
\text { mineral extraction } \\
\text { and biomass } \\
\text { production } \\
\text { which are } \\
\text { associated } \\
\text { with household } \\
\text { consumption } \\
\text { I.E Households' } \\
\text { debt } \\
\text { I.F } \\
\text { The employment } \\
\text { rate of older } \\
\text { workers } \\
\text { I.G The old-age } \\
\text { index and } \\
\text { the dependency } \\
\text { index }\end{array}$ & $\begin{array}{l}\text { II.A GDP } \\
\text { per capita } \\
\text { II.B Labour } \\
\text { productivity } \\
\text { II.C General } \\
\text { unemployment rate } \\
\text { II.D Transport } \\
\text { density } \\
\text { II.E Energy } \\
\text { intensity of GDP } \\
\text { II.F Consumption } \\
\text { of primary energy } \\
\text { sources } \\
\text { II.G } \\
\text { The proportion } \\
\text { of energy } \\
\text { from renewable } \\
\text { sources } \\
\text { II.H Material } \\
\text { consumption } \\
\text { II.I Surface water } \\
\text { and groundwater } \\
\text { extraction by sector } \\
\text { II.J Waste } \\
\text { management } \\
\text { according to the } \\
\text { main management } \\
\text { methods } \\
\text { II.K Education } \\
\text { level structure } \\
\text { II.L Expenditure } \\
\text { on research and } \\
\text { development } \\
\text { II.M Access to the } \\
\text { Internet }\end{array}$ & $\begin{array}{l}\text { III.A GDP per } \\
\text { capita } \\
\text { III.B General } \\
\text { unemployment rate } \\
\text { III.C Expenditure } \\
\text { on research and } \\
\text { development and } \\
\text { the number } \\
\text { of employees } \\
\text { in research and } \\
\text { development } \\
\text { III.D } \\
\text { Municipalities that } \\
\text { are involved } \\
\text { implementing } \\
\text { the local Agenda } 21 \\
\text { method } \\
\text { III.E Migration } \\
\text { balance of rural } \\
\text { communities } \\
\text { III.F Revenue per } \\
\text { capita and debt } \\
\text { service } \\
\text { III.G Passenger } \\
\text { transport by public } \\
\text { road and rail } \\
\text { transport } \\
\text { III.H Access } \\
\text { to the Internet } \\
\text { III.I The number } \\
\text { of people in shared } \\
\text { accommodation } \\
\text { establishments } \\
\text { III.J Public budget } \\
\text { expenditure } \\
\text { on culture } \\
\text { III.K The coverage } \\
\text { of the territory } \\
\text { with approved land- } \\
\text { in the total area } \\
\text { use planning } \\
\text { inicipalities } \\
\text { intion areas } \\
\text { ing }\end{array}$ & $\begin{array}{l}\text { IV.A The indicator } \\
\text { of changes } \\
\text { in the territory and } \\
\text { ecosystems } \\
\text { IV.B Index } \\
\text { of common species } \\
\text { of wild birds } \\
\text { IV.C Expenditure } \\
\text { on environmental } \\
\text { protection and } \\
\text { public expenditure } \\
\text { on environmental } \\
\text { protection } \\
\text { IV.D Consumption } \\
\text { of basic nutrients } \\
\text { in mineral } \\
\text { fertilizers } \\
\text { IV.E } \\
\text { The proportion } \\
\text { of organic farming } \\
\text { IV.F Deforestation } \\
\text { IV.G The intensity } \\
\text { of logging }\end{array}$ & $\begin{array}{l}\text { V.A Corruption } \\
\text { perception index } \\
\text { V.B Participation } \\
\text { in election } \\
\text { V.C The population } \\
\text { living below } \\
\text { the poverty line } \\
\text { before and after } \\
\text { social transfers } \\
\text { V.D General } \\
\text { government balance } \\
\text { and debt } \\
\text { V.E The average } \\
\text { length of judicial } \\
\text { proceedings } \\
\text { V.F Total } \\
\text { international } \\
\text { development } \\
\text { cooperation } \\
\text { V.G Greenhouse } \\
\text { gas emissions per } \\
\text { capita and per unit } \\
\text { of GDP } \\
\text { V.H Foreign direct } \\
\text { investment }\end{array}$ \\
\hline
\end{tabular}




\section{SUSTAINABLE TRANSPORT}

Transport is one of the crucial areas of the Czech economy with considerable significance for international relations. The transport passenger and freight demand rises steadily and it is necessary to create legal and economic conditions for providing public services in transport and to provide the infrastructure corresponding with the growth in transport needs (Adamec et al., 2005). Sustainable transport can be defined as services which create conditions for passenger and freight transport, which, on the one hand, is functional, safe, and economic, and on the other hand, is not in contrast with the sustainable consumption of natural resources, decreases the impact on the environment and eliminates the negative impacts on human health (Kušková, 2003). The effort to address this problem in the Czech Republic and its focus on sustainability has to be focused in two directions. Transport system optimization and the promotion of the sustainable transport principles in the society is the first one. The aim of this strategy is to achieve effective and optimum passenger and freight transport, a lower use of motor vehicles, a higher use of urban public transport, and a better capacity use of vehicles and non-motorized means of transport. The promotion of higher ecoefficiency for the means of transport, especially cars, is the second task. This means not only to continue to increase of the efficiency of engines and improving the effectiveness of the catalytic systems for capturing the emissions of combustion engines, but also to introduce and promote alternative types of fuel, to be common and affordable for the standard user. The development of transport and transport systems is long-planned and implemented through transport policies in individual countries. The general objective of the sustainable transport policy is to create conditions for meeting the sustainable transport development in a way which is defined above. It is apparent that meeting such objective is a difficult task - traffic considerably influences the economic, social, and environmental dimensions of life, is deeply rooted in the majority of major components of society, and its extensive development is can only be changed with great difficulties in most countries.

The issue of sustainable development is also defined in the SRUR ČR, in priority axis 2 Economics and innovation priority, 2.1- Supporting the dynamics of the national economy and improving competitiveness (in industry and business, agriculture, services), Objective 4 Improving transport quality, efficiency and safety. The goal comes from the needs laid on transport sustainability, the reduction of emissions including noise, and the increase in the energy efficiency of transport. It is necessary to complete the basic network infrastructure of railway and road transport (network TEN-T and important linked routes of national and regional importance) and to construct the missing safety infrastructure for bicycle transport. Likewise, it is necessary to support the implementation of traffic engineering and traffic organizational measures, both for transit traffic exclusion from populated areas, or to increase the road traffic flow in general (for a considerable reduction of pollutant emissions and carbon dioxide). Construction has to be implemented with limited negative impact on important localities concerning the natural value, the fragmentation of landscape, and its migratory conditions. It is also necessary to modernize railway transport and control its function as a backbone transport network in terms of freight and passenger transport, considering the lower external losses. Furthermore, to enhance energy efficiency and the economic efficiency of transport, reduce emissions from transport and prepare for the oil peak. It is necessary to support public transport and the terminal networks of multi-modal transportation, including multi-modal public logistics centres based mainly on rail transport. It is necessary to provide quality transport services and to enhance traffic safety and introduce telematics applications in all transport modes. An important goal is also to introduce an appropriate system of price determination for using the transport infrastructure and to internalize external losses in transport prices. 


\section{INDICATORS OF SUSTAINABLE TRANSPORT DEVELOPMENT}

Transport importance in the sustainable development of the Czech Republic is reflected by the SUR ČR and the SRUR ČR, where the selected transport indicators are part of a set of indicators used for the regular monitoring of meeting the determined objectives.

Table 4: Strategic objectives of the SUR.

\begin{tabular}{|c|c|}
\hline Strategic objectives & Indicators \\
\hline \multirow[b]{3}{*}{$\begin{array}{l}\text { Separation of economic } \\
\text { growth and demand } \\
\text { for transport in order } \\
\text { to reduce negative impacts. }\end{array}$} & Transport in freight transport. \\
\hline & Number of public logistics centres. \\
\hline & $\begin{array}{l}\text { The rate achieved by internalization of the external } \\
\text { damage of individual transport modes expressed } \\
\text { as a percentage of the total external damage, furthermore } \\
\text { absolute value expressed in CZK and a price share } \\
\text { according to the EU schedule in } 2009 \text { (on the basis } \\
\text { of methodology adopted by the EU). }\end{array}$ \\
\hline \multirow{7}{*}{$\begin{array}{l}\text { Achieving sustainable levels } \\
\text { of using energy in transport } \\
\text { and a reduction in emissions } \\
\text { of greenhouse gases } \\
\text { from transport. }\end{array}$} & $\begin{array}{l}\text { Greenhouse gas emissions from transport divided } \\
\text { into fossil sources and sources from the biomass. }\end{array}$ \\
\hline & The consumption of individual fuels (tonne/year). \\
\hline & Air transport emissions (person and kilometre). \\
\hline & Number of CNG filling stations. \\
\hline & Number of vehicles running on CNG. \\
\hline & $\begin{array}{l}\text { increase the energy efficiency of transport through } \\
\text { technological modernization and logistics. }\end{array}$ \\
\hline & $\begin{array}{l}\text { Carbon dioxide emissions from motor vehicles } \\
\text { in the Czech Republic. }\end{array}$ \\
\hline \multirow{3}{*}{$\begin{array}{l}\text { The reduction of transport } \\
\text { pollutant emissions to levels } \\
\text { which minimize possible } \\
\text { influence on human health } \\
\text { or the environment. }\end{array}$} & Transport share on total air pollution (\%). \\
\hline & $\begin{array}{l}\text { The overall transport emissions }\left(\mathrm{PM} 10, \mathrm{PAH}, \mathrm{NO}_{\mathrm{x}} \text {, }\right. \\
\mathrm{NO}_{2} \text {, VOC, benzene, } \mathrm{SO}_{2}, \mathrm{CO}, \mathrm{CO}_{2} \text {, some metals } \\
\text { and PM2,5 - overview). }\end{array}$ \\
\hline & $\begin{array}{l}\text { emissions of the individual means of transport (per } \mathrm{t} \mathrm{km} \text {, } \\
\text { person } \mathrm{km} \text { ). }\end{array}$ \\
\hline \multirow[t]{3}{*}{ Improvement of safety. } & $\begin{array}{l}\text { The development of accident rates (number of deaths, } \\
\text { injured with apallic syndrome, i.e. irreversible diffuse } \\
\text { damage of cerebral cortex, the severely injured, material } \\
\text { damage). }\end{array}$ \\
\hline & $\begin{array}{l}\text { Number of deaths, slightly or seriously injured people } \\
\text { in traffic accidents. }\end{array}$ \\
\hline & Number of accidents with hazardous cargo. \\
\hline \multirow{3}{*}{$\begin{array}{l}\text { Achieving the appropriate } \\
\text { modal split according } \\
\text { to the co-modality principle. }\end{array}$} & Number of km of road with performance charging $(\mathrm{km})$. \\
\hline & $\begin{array}{l}\text { The share of transported performance of road freight } \\
\text { in comparison to railway and water freight } \\
\text { transport }(\%) \text {. }\end{array}$ \\
\hline & $\begin{array}{l}\text { The share of railway transport on transport } \\
\text { performance }(\%) \text {. }\end{array}$ \\
\hline
\end{tabular}

The area of transport is represented in SRUR ČR by two indicators in Priority axis 2: Economics and innovations, by indicator II.D Transport intensity and in Priority axis 3: Land 
use development, by indicator III.G Public passenger transport by road and railway. The indicator II.D Transport intensity is defined as the ratio of traffic volumes and GDP (person/km per CZK 1000, tkm per CZK 1000) and it is used for assessing whether it comes to trends in GDP and transported operation. This separation is desirable because the significant effects on the environment are connected with transport performance as well. The indicator III.G Public passenger transport by road and railway is defined as the number of trips by railway and public bus transport realized by one inhabitant of the region (number per capita). The indicator significance lies in the fact that the reduced transport services of the regions cause problems in commuting to work, as well as services. Public transport has lower environmental impacts than car transport and has a crucial importance in increasing transport services.

In the gradual updating of the SUR a definition of clear goals appears where the aim for transport should be within the Czech Republic and these objectives are specified by other indicators which determine the meeting of these strategic goals.

\section{SUMMARY}

Regarding the above mentioned information it is apparent that the issue of sustainable development and sustainable transport is very broad, complex, and complicated. In spite of this, it is necessary to realize that increasing mobility does not only have a positive contribution to the society, but it also brings a large amount of negative impacts which we should try to prevent. Experience, however, points towards a clear instruction that sustainable development is impossible without an adequate economic policy. The task will remain to produce the sustainable transport development strategy in accordance with international recommendations which would satisfy the needs of current generations without being an unbearable burden for future generations. The indispensable part of the strategy is also a set of indicators which will be used for the monitoring the implementation of individual strategic objectives and a subsequent comparison of development on the international level, which will enable the possible revision of the designed measures for the sustainable development of transport.

\section{ACKNOWLEDGEMENTS}

The research described in this article was established within the research project of the Ministry of Transport of the Czech Republic No. MD 04499457501 "Sustainable Transport - Chance for the Future" and research and development project No. CG712-093520 "Indicators utilization for regional development assessment according to sustainable transport".

\section{REFERENCES}

Adamec, V., Dostál, I., Dvořáková, P., Huzlík, J., Cholava, R., Jandová, V., Jedlička, J., Pokorná, B., Smékal, P., Šed'a, V., Šucmanová, M., 2005. Elektronický průvodce udržitelnou dopravou [online]. Brno: CDV, 118 p. [cit. 2006-04-21]. Retrieved from: http://www.cdv.cz/text/szp/clanky/pruvodce_beta.pdf (in Czech)

Bruntland, G., 1987. Our common future: The World Commission on Environment and Development. Oxford: Oxford University Press. ISBN 0-19-282080-X. 
European Commission, 2001. White paper - "European transport policy for 2010 : time to decide“. Luxembourg: Office for Official Publications of the European Communities, 119 p. ISBN 92-894-0341-1.

Government of the Czech Republic, 2004. Strategie udržitelného rozvoje České republiky. Praha: Office of the Government, $59 \mathrm{p}$.

Governmental Concil for Sustainable Development, 2010. Strategic framework for Sustainable Development in the CR. Praha: Ministry of the Environment, 105 p. ISBN 978-80-7212-536-4.

Janic, M., 2006. Sustainable Transport in the European Union: A review of the Past Research and Future Ideas. Transport Review, vol. 26, no. 1, pp. 81-104. ISSN 0144-1647.

Kušková, P., 2003. Česká republika 2003: Deset let udržitelného rozvoje? Praha: Centrum pro otázky životního prostředí UK, 72 p. ISBN 80-239-2010-3.

Malthus, T. K., Flew, A., 1983. An Essay on the Principle of Population. London: Penguin Classics, 304 p. ISBN-10: 014043206X.

Marks, D.H., 2002. The Evolving role of Systems Analysis in Process and Methods in LargeScale Public Socio-Technical Systems [online]. Massachusetts Institute of Technology, Engineering Systems Division. Working paper Series, ESD-WP-2003-01.08-ESD, Internal Symposium, May 29-30, 2002 [cit. 2007-06-14]. Retrieved from: http://esd.mit.edu/WPS/internal-symposium/esd-wp-2003-01.08.pdf

Meadows, D.H., Meadows, D.L., Randers, J., 1992. Beyond the Limits. Vermont: Chelsea Green Publishing Company, 320 p. ISBN-10: 0930031628

Mill, J. S., 2004. Principles of Political Ekonomy. New York: Prometheus Books, 892 p. ISBN-10: 1591021510.

Moldan, B., 2001. Ekologická dimenze udržitelného rozvoje. Praha: Karolinum, 102 p. ISBN 80-246-0246-6. (in Czech)

Moldan, B., Hák, T., Kolářová, H., 2002. K udržitelnému rozvoji České republiky: vytváření podmínek. Praha: Centrum pro otázky životního prostředí UK, 1852 p. ISBN 80-2388378-X. (in Czech)

Třebícký, V., Novák, J., Kružíková, E., 2001. Proměny politiky životního prostředí. Praha: Ústav pro ekopolitiku, o.p.s., 62 p. (in Czech) 